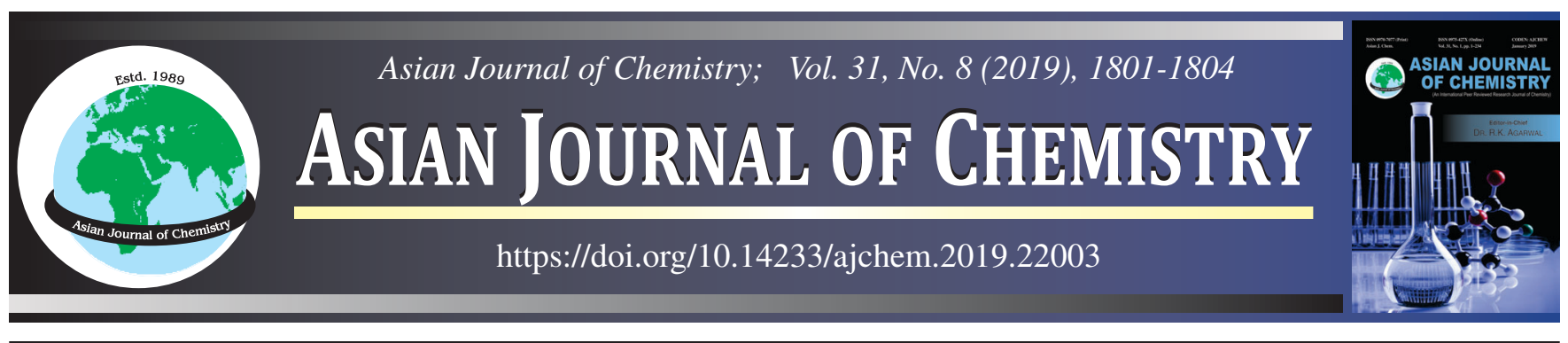

\title{
High Performance Liquid Chromatography Analysis Using Rutin Marker and Estimation of Phenolic \& Flavonoid Compounds in the Extracts of Indian Medicinal Plant Morus nigra L.
}

\author{
Sunita Singh ${ }^{1}$, Alka Tripathi ${ }^{2}$, V.K. LaL ${ }^{3}$ and Dhananjay Singh ${ }^{4}{ }^{*}$
}

${ }^{1}$ Department of Pharmacy, Rameshwaram Institute of Technology \& Management, Lucknow-227202, India

${ }^{2}$ Department of Applied Sciences, Institute of Engineering \& Technology, Lucknow-226021, India

${ }^{3}$ Lavanya Ayurveda Hospital, Chinhat, Lucknow-227105, India

${ }^{4}$ Department of Chemical Engineering, Institute of Engineering \& Technology, Lucknow-226021, India

*Corresponding author: E-mail: dsa768008@gmail.com

Received: 15 February 2019;

Accepted: 9 April 2019;

Published online: 28 June 2019;

AJC-19455

Morus nigra L. (black mulberry) belongs to moraceae family of Indian medicinal plants. Black mulberry has significant anticancerous,
antioxidant, antidiabetic, antimicrobial and antiobesity activities. Rutin marker was used for high performance liquid chromatography
technique. We used gallic acid and quercetin for phenolic compound determination and flavonoid content determination in plant
leaf extract. Plant extract of this species was analyzed quantitatively and qualitatively through high pressure liquid chromatography.
Rutin compound was the main marker, which is a flavonoidal compound. Standard solution $(1 \mathrm{mg} / \mathrm{mL})$ of rutin was prepared by using
$\mathrm{CH}_{3} \mathrm{OH}$. Methanol:water $(80: 20, \mathrm{v} / \mathrm{v}) \mathrm{ratio}$ was used to dissolve powdered $M$. nigra plant leaves $(100 \mathrm{mg})$, in which $0.01 \mathrm{mg} / \mathrm{g}$ rutin
content was found. Total phenolic content in $M$. nigra was found $43.15 \pm 0.68 \mathrm{mg} / \mathrm{g}$ GAE (gallic acid equivalents). Total flavonoid content
in $M$. nigra was found $5.8 \pm 0.46 \mathrm{mg} / \mathrm{g}$ QE. It was found that the $M$. nigra has not significant rutin potency and found to be as 0.01
$\mathrm{mg} / \mathrm{g}$.

\section{INTRODUCTION}

Plants contain biologically active compounds to treat severe as well as infectious diseases. Herbal drugs have no side effects and less expensive as compared to synthetic drugs, so it may easily reachable to poor people. Almost all parts of the plant are used as medicine such as leaves, fruits, flowers, seeds, roots, barks, stems and peels [1-4].

Morus nigra (black mulberry) belongs to moraceae family. It is known as 'Shahtoot' (Hindi), Tuta (Sanskrit), Tuti (Marathi) and Toot (Persian). Plant contain tannins, saponins, terpenoids, flavonoids, sitosterols, morusimic acid, anthocyanins glycosides and alkaloids are main active principles [5-8]. Mulberry plants are widely cultivated to feed the silkworm. It is an economically important plant used in sericulture. The pupa (cocoon) which is used to make silk. It is also used as diuretic, antiulcer, antibacterial, laxative, anticancer, antimicrobial, antioxidant, antihypertensive, antihyperglycemic, antihyperlipidemic, brain tonic and antidiabetic [9-11].
Morus nigra is a medium or small sized deciduous tree, 6 to $9 \mathrm{~m}$ in height and 1.5-3.0 $\mathrm{m}$ in diameter. Leaves are variable, in size and shape, usually 7 to $12 \mathrm{~cm}$ long, simple, alternate, broadly ovate-cordate, serrate usually undivided, sometimes 1-2 lobed, thick, 3-nerved. Flowers are monoecious or dioecious, greenish yellow with brown stigma branches. Inflorescence are catkin type, sepals and styles are densely hairy [12-15]. Trunk bark of grown-up trees are brownish gray, consisting of narrow strips that are separated by shallow furrows. It is native of south western Asia and cultivated in many countries for its edible fruits. It has an ovoid to oblong composite fruit. Colour of fruits is dark purple, almost black after ripenning, 2-3 centimeters in length. It is a compound cluster of several tiny drupes. The black colour of fruits is due to the presence of anthocyanins [16-18].

High performance liquid chromatography (HPLC) technique is used for the separation, detection, purification and quantification of the various components of the natural products (bioactive compounds) such as rutin, quercetin, ellagic acid, chloro-

This is an open access journal, and articles are distributed under the terms of the Attribution 4.0 International (CC BY 4.0) License. This license lets others distribute, remix, tweak, and build upon your work, even commercially, as long as they credit the author for the original creation. You must give appropriate credit, provide a link to the license, and indicate if changes were made. 
genic acid, etc. [19]. Its fingerprinting patterns show the presence of multiple compound in the sample. By comparing the retention times of the samples against the standards, known peaks were identified. This method is also used for the determination of meloxicam in human serum. Meloxicam, a non-steroidal drugs, is used as antipyretic, anti-inflammatory and analgesic drug [20].

\section{EXPERIMENTAL}

HPLC analysis: The sample of dried leaves (100 mg) of Morus nigra was subjected to solvent $\left(3 \times 10 \mathrm{~mL}, \mathrm{H}_{2} \mathrm{O}: \mathrm{CH}_{3} \mathrm{OH}\right.$ $20: 80, \mathrm{v} / \mathrm{v})$ in ultrasonic exposure $(30.0 \mathrm{~cm} \times 25.0 \mathrm{~cm} \times 12.5$ $\mathrm{cm}$ at $34 \pm 3 \mathrm{kHz}$, Mumbai, India) at $40^{\circ} \mathrm{C}$. Centrifugation (3920 $\mathrm{g}$ for $10 \mathrm{~min}$ ) was also applied. Standard solution (1 $\mathrm{mg} / \mathrm{mL}$ ) of rutin was prepared in $\mathrm{CH}_{3} \mathrm{OH}$ [21-24].

Fingerprint profile of Morus nigra was developed according to previous HPLC reported methods with some changes. Separation was done with optimized solvent composition of acidified $\mathrm{H}_{2} \mathrm{O}$ and $\mathrm{CH}_{3} \mathrm{OH}$ by applying Phenomenax Luna (250 $\times 4.6 \mathrm{~mm}, 5 \mu \mathrm{m}) \mathrm{C}_{18}$ column [25-27]. Applied marker, rutin was confirmed by retention time and UV-spectra matching in the sample and quantified by external standard method [28,29].

Estimation of total phenolic contents: Folin-Ciocalteu reagent and gallic acid were used for the determination of phenolic compounds in alcoholic extract of $M$. nigra [30,31]. $100 \mathrm{mg}$ of gallic acid was dissolved in $100 \mathrm{~mL}$ of $\mathrm{CH}_{3} \mathrm{OH}$, for the preparation of stock solution $(1.0 \mathrm{mg} / \mathrm{mL})$. Different curves (for calibration) were found by using $1 \mathrm{~mL}$ aliquots (gallic acid solutions) of $2.5,5.0,10,20,30,40$ and $50 \mu \mathrm{g} / \mathrm{mL}$ solutions of gallic acid with $5.0 \mathrm{~mL}$ of Folin-Ciocalteu reagent and $4 \mathrm{~mL}$ of $7.5 \% \mathrm{Na}_{2} \mathrm{CO}_{3}$ solution [32-34]. Then, $100 \mathrm{~mL}$ of ethanol, having purity of $95 \%$ was mixed with $10 \mathrm{~mL}$ of extracts (morus leaves) for the preparation of stock solution. The concentration of $100 \mu \mathrm{g} / \mathrm{mL}$ of leaf extracts were also made by using ethanol having purity of $95 \%$. The measurement of absorbance of reaction samples were done at $760 \mathrm{~nm}$ by using UV-visible spectrophotometer (Lasany, Li-2800 series). For the better estimation, every run was analyzed in triplicate $[35,36]$.

Estimation of total flavonoid contents: As a standard compound, quercetin was used for estimation of flavonoids [37]. The concentration of $100 \mu \mathrm{g} / \mathrm{ml}$ of leaf extracts were made by using $\mathrm{CH}_{3} \mathrm{OH}$ having purity of $95 \%$. Every sample of $0.5 \mathrm{~mL}$ was introduced into a separated test tubes and added with $1.5 \mathrm{~mL}$ of $\mathrm{CH}_{3} \mathrm{OH}, 0.1 \mathrm{~mL}$ of $10 \% \mathrm{AlCl}_{3}, 0.1 \mathrm{~mL}$ of $1.0 \mathrm{M}$ $\mathrm{CH}_{3} \mathrm{COOK}$ and $2.8 \mathrm{~mL}$ of distilled water. The measurement of absorbance of reaction samples were done at $760 \mathrm{~nm}$ by using a UV spectrophotometer (Lasany, Li-2800 series). For the better estimation, every run was analyzed in triplicate [38-40].

\section{RESULTS AND DISCUSSION}

HPLC chromatogram of standared compound i.e. rutin is the process of confirmation of the responsible for antidiabetic activity of Morus nigra. Fig. 1 shows the HPLC chromatogram indicating the detection of rutin (39.531 min) in Morus nigra L. species. The values were estimated at 254 and $4 \mathrm{~nm}$.

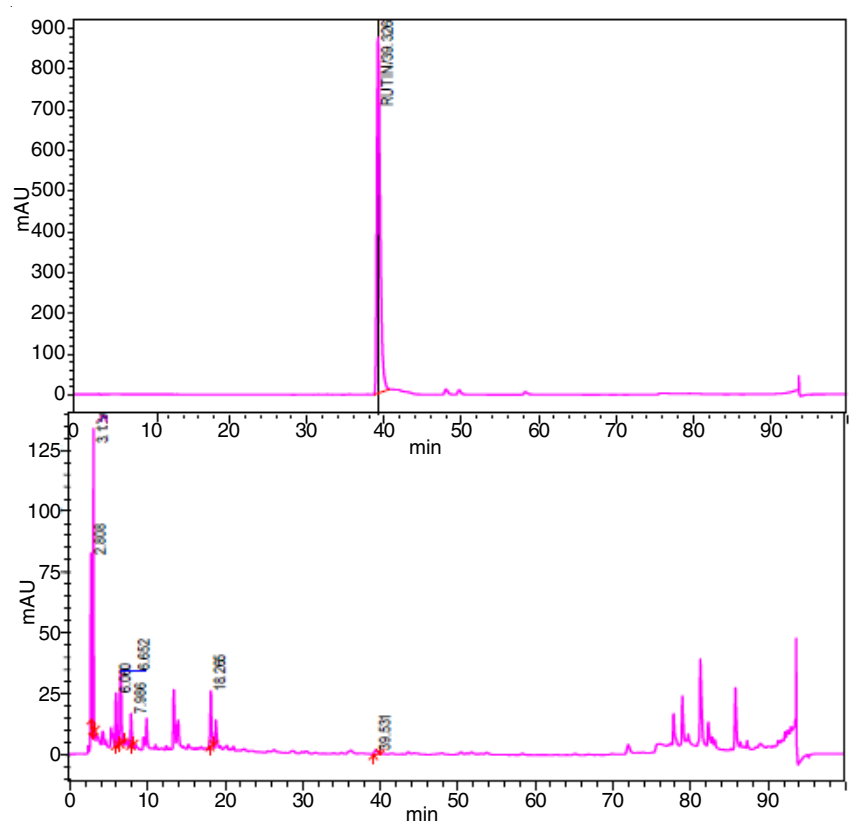

Fig. 1. The comparative HPLC chromatogram for rutin determination in $M$. nigra species

Based on the modified HPLC method by modifying the mobile phase gradient and the sample dilution and also including the markers of quercetin and total flavonoids besides rutin. All chromatographic peaks exhibited typical flavonoid UV absorption profiles, and so peaks 3 (rutin), 4 (isoquercitrin), 5 (unknown) and 7 (quercetin) (Fig. 2) were expressed as rutin to monitor the stability of the Morus nigra L. species. Thus total phenolic and flavonoid contents can be determined and the results are shown in Table-1.

Excel 2007 software was used for data analysis. The spectrophotometric determinations represent the average (mean) \pm standard deviation in triplicate. The quantity of total phenolic content in extract was estimated by a linear gallic

TABLE-1

TOTAL PHENOLIC AND TOTAL FLAVONOID CONTENTS OF $M$. nigra

\begin{tabular}{|c|c|c|c|c|c|c|c|}
\hline \multicolumn{4}{|c|}{ Total phenolic: Standard compound (gallic acid) $\lambda_{\max } 760 \mathrm{~nm}$} & \multicolumn{4}{|c|}{ Total flavonoid: Standard compound (quercetin) $\lambda_{\max } 760 \mathrm{~nm}$} \\
\hline \multirow{2}{*}{$\begin{array}{l}\text { Concentration } \\
(\mu \mathrm{g} / \mathrm{mL})\end{array}$} & \multicolumn{3}{|c|}{ Absorbance (nm) } & \multirow{2}{*}{$\begin{array}{c}\text { Concentration } \\
(\mu \mathrm{g} / \mathrm{mL})\end{array}$} & \multicolumn{3}{|c|}{ Absorbance (nm) } \\
\hline & $\mathrm{A} 1$ & $\mathrm{~A} 2$ & $\mathrm{~A} 3$ & & A1 & $\mathrm{A} 2$ & A3 \\
\hline 2.5 & 0.0299 & 0.0389 & 0.0412 & 0.8 & 0.0416 & 0.0451 & 0.0463 \\
\hline 5 & 0.0335 & 0.0457 & 0.0435 & 1.6 & 0.0465 & 0.0513 & 0.0476 \\
\hline 10 & 0.0386 & 0.0597 & 0.0489 & 3.12 & 0.0532 & 0.0557 & 0.0518 \\
\hline 20 & 0.0478 & 0.084 & 0.0598 & 6.25 & 0.0746 & 0.0682 & 0.0624 \\
\hline 30 & 0.0587 & 0.109 & 0.0703 & 12.5 & 0.1083 & 0.0905 & 0.0782 \\
\hline 40 & 0.0676 & 0.1337 & 0.0823 & 25.0 & 0.1887 & 0.1431 & 0.1065 \\
\hline
\end{tabular}



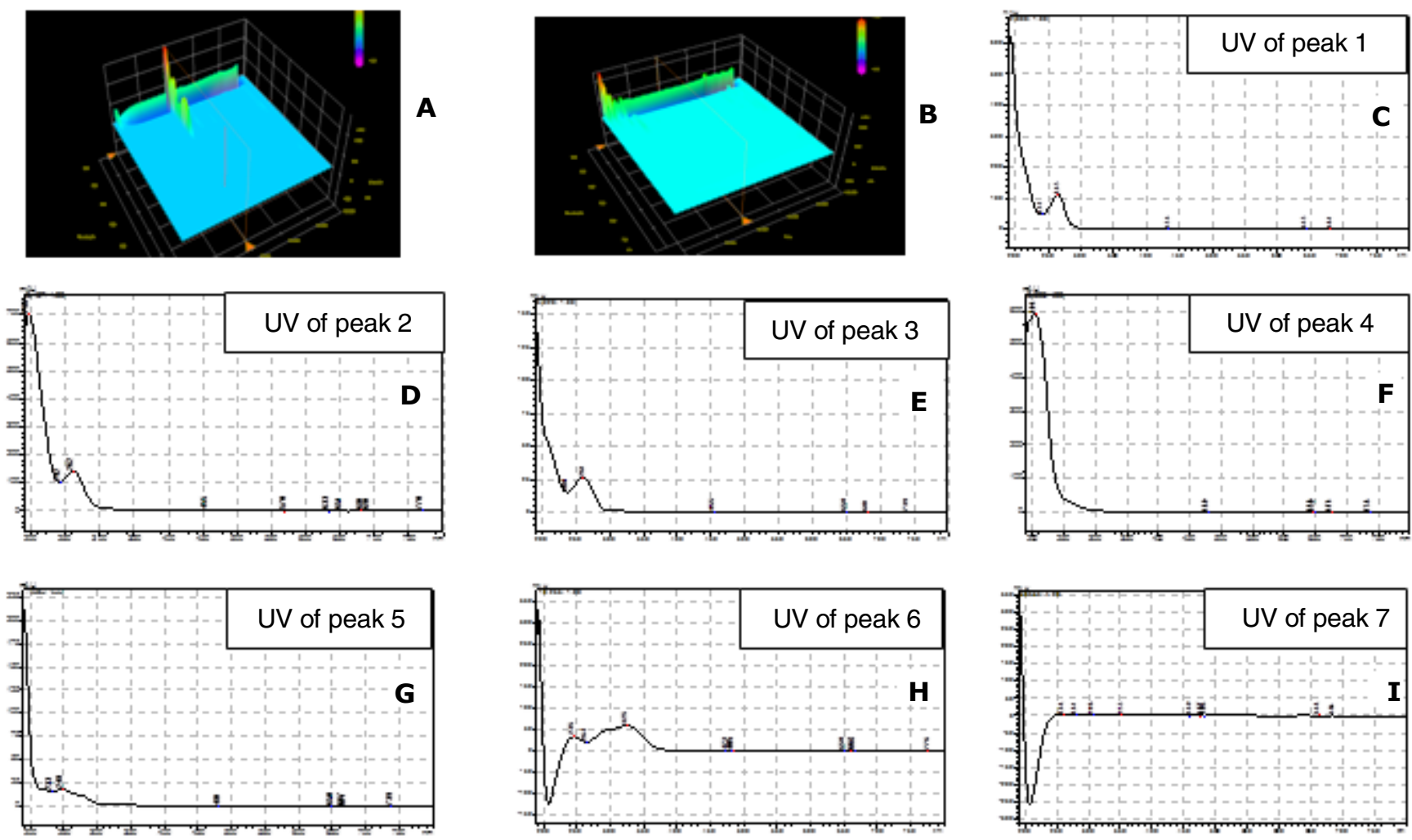

Fig. 2. The rutin marker in M. nigra was confirmed by UV-spectra matching in the samples and quantified by external standard method. A: fingerprint of rutin marker, B: fingerprint of rutin in M. nigra, C, D, E, F, G, H, I: are peaks at retention times 2.808, 3.129, 6.060, $6.652,7.986,18.265,39.531$ respetively

acid standard curve (standard curve equation $\mathrm{y}=0.001 \mathrm{x}+$ $0.0281, R^{2}=0.9986$ ). Standard compound (gallic acid) and the total phenolic content was expressed as $\mathrm{mg} / \mathrm{g}$ GAE (gallic acid equivalents). The total phenolic content in Morus nigra was found $43.15 \pm 0.68 \mathrm{mg} / \mathrm{g}$ GAE. Moreover, linear standard quercetin curve was used to estimate flavonoid compounds in the extract (standard curve equation $\mathrm{y}=0.0061 \mathrm{x}+0.0357, \mathrm{R}^{2}$ $=0.9989$ ), while total flavonoid contents in Morus nigra was found to be $5.8 \pm 0.46 \mathrm{mg} / \mathrm{g} \mathrm{QE}$ (quercetin equivalents).

\section{Conclusion}

Plant leaf extract of Morus nigra was analyzed by high pressure liquid chromatography (HPLC) for qualitative and quantitative analyses. The total phenolic contents in Morus nigra was estimated as $43.15 \pm 0.68 \mathrm{mg} / \mathrm{g}$ GAEm while the total flavonoid contents in Morus nigra was found to be $5.8 \pm$ $0.46 \mathrm{mg} / \mathrm{g}$ QE. It was also found that Morus nigra has not significant rutin potency due to its low contents $(0.01 \mathrm{mg} / \mathrm{g})$.

\section{CONFLICT OF INTEREST}

The authors declare that there is no conflict of interests regarding the publication of this article.

\section{REFERENCES}

1. H. Chen, J. Pu, D. Liu, W. Yu, Y. Shao, G. Yang, Z. Xiang and N. He, PLoS One, 11, e0153080 (2016);

https://doi.org/10.1371/journal.pone.0153080.

2. Y. Jiang and W.J. Nie, Food Chem., 174, 460 (2015); https://doi.org/10.1016/j.foodchem.2014.11.083.
3. K.T. Park, J.K. Kim, D. Hwang, Y. Yoo and Y.H. Lim, Food Chem. Toxicol., 49, 3038 (2011);

https://doi.org/10.1016/j.fct.2011.09.008.

4. P. Supritha and K.V. Radha, Indian J. Pharm. Educ. Res., 52, 321 (2018); https://doi.org/10.5530/ijper.52.2.37.

5. H.M. Tag, BMC Complement. Altern. Med., 15, 252 (2015); https://doi.org/10.1186/s12906-015-0744-y.

6. O. Mazimba, R.R.T. Majinda and D. Motlhanka, Afr. J. Pharm. Pharmacol., 5, 751 (2011); https://doi.org/10.5897/AJPP11.260.

7. Z.-P. Zheng, K.-W. Cheng, Q. Zhu, X.-C. Wang, Z.-X. Lin and M. Wang, J. Agric. Food Chem., 58, 5368 (2010);

https://doi.org/10.1021/jf1003607.

8. A.V. Yadav, L.A. Kawale and V.S. Nade, Indian J. Pharmacol., 40, 32 (2008).

9. C. Chang, M. Yang, H. Wen and J. Chen, J. Food Drug Anal., 10, 178 (2002).

10. E.M. Sánchez-Salcedo, M. Tassotti, D. Del Rio, F. Hernández, J.J. Martínez and P. Mena, Food Chem., 212, 250 (2016); https://doi.org/10.1016/j.foodchem.2016.05.121.

11. A. Hunyadi, A. Martins, T.J. Hsieh, A. Seres and I. Zupko, PLoS One, 7, e50619 (2012); https://doi.org/10.1371/journal.pone.0050619.

12. D.A. Kostic, D.S. Dimitrijevic, S.S. Mitic, M.N. Mitic, G.S. Stojanovic and A.V. Zivanovic, Trop. J. Pharm. Res., 12, 105 (2013); https://doi.org/10.4314/tjpr.v12i1.17.

13. A.M.A. Mawla, K.M. Mohamed and A.M. Mostafa, Sci. Pharm., 79, 951 (2011); https://doi.org/10.3797/scipharm.1101-15.

14. Y.K. Walia, Asian J. Adv. Basic Sci., 1, 40 (2013).

15. G.T. Volpato, I.M.P. Calderon, S. Sinzato, K.E. Campos, M.V.C. Rudge and D.C. Damasceno, J. Ethnopharmacol., 138, 691 (2011); https://doi.org/10.1016/j.jep.2011.09.044.

16. Anonymous, The Wealth of India: A Dictionary of Raw Materials and Industrial Products-Raw Materials, Council of Science and Industrial Research, vol. 7, 429 (1952). 
17. K.M. Nadkarni, Indian Materia Medica, with Ayurvedic, Unani-Tibbi, Siddha, Allopathic, Homeopathic, Naturopathic \& Home Remedies, Popular Prakashan: Bombay, India, p. 816 (1982).

18. K.R. Kirtikar and B.D. Basu, Indian Medicinal Plant, vol. 3, p. 2306 (1984).

19. S.B. Sharma, S. Gupta, A.C. Rini, U.R. Singh, R. Rajpoot and S.K. Shukla, J. Pharm. Pharmacol., 62, 247 (2010); https://doi.org/10.1211/jpp.62.02.0013.

20. S.S.A. Hameed, S.A. Bazaid and M.M. Shohayeb, Chem. Pap., 68, 1358 (2014); https://doi.org/10.2478/s11696-014-0570-6.

21. M. Scordino, L. Sabatino, P. Traulo, M. Gargano, V. Panto and G. Gagliano, Eur. Food Res. Technol., 232, 275 (2011); https://doi.org/10.1007/s00217-010-1386-4.

22. U. Supe and P. Daniel, Am.-Eur. J. Agric. Environ. Sci., 15, 2196 (2015); https://doi.org/10.5829/idosi.aejaes.2015.15.11.12733.

23. H.N.T. Pham, Q.V. Vuong, M.C. Bowyer and C.J. Scarlett, Chem. Pap., 71, 2233 (2017); https://doi.org/10.1007/s11696-017-0216-6.

24. J. Engsuwan, N. Waranuch, N. Limpeanchob and K. Ingkaninan, Sci. Asia, 43, 169 (2017); https://doi.org/10.2306/scienceasia1513-1874.2017.43.169.

25. J. Agrawal, K. Shanker, D. Chanda and A. Pal, Parasitol. Res., 112, 2601 (2013); https://doi.org/10.1007/s00436-013-3427-y.

26. S. Singh, Asian J. Biochem. Pharm. Res., 2, 388 (2012).

27. U.A. Fischer, R. Carle and D.R. Kammerer, Food Chem., 127, 807 (2011); https://doi.org/10.1016/j.foodchem.2010.12.156.

28. X.Y. Wang, Q. Liang, H.G. Chen and X. Zhou, Chem. Pap., 72, 2255 (2018); https://doi.org/10.1007/s11696-018-0459-x.
29. M. Vani, S.A. Rahaman and A.P. Rani, Pharmacogn. J., 10, 439 (2018); https://doi.org/10.5530/pj.2018.3.72.

30. Q.V. Vuong, S. Hirun, P.D. Roach, M.C. Bowyer, P.A. Phillips and C.J. Scarlett, J. Herb. Med., 3, 104 (2013); https://doi.org/10.1016/j.hermed.2013.04.004.

31. A. Charoensuk, M. Jaroensutasinee and K. Jaroensutasinee, J. Environ. Biol., 39, 387 (2018); https://doi.org/10.22438/jeb/39/3/MRN-611.

32. D.A.S. Shammaa, Res. J. Sci. IT Manag., 3, 30 (2014).

33. D.J. Bhuyan, Q.V. Vuong, A.C. Chalmers, I.A. Altena, M.C. Bowyer and C.J. Scarlett, Chem. Pap., 70, 567 (2016); https://doi.org/10.1515/chempap-2015-0237.

34. F. Pourmorad, S.J. Hosseinimehr and N. Shahabimajd, Afr. J. Biotechnol., 5, 1142 (2006)

35. G.A. Naderi, S. Asgary, N. Sarraf-Zadegan, H. Oroojy and F. AfshinNia, Phytother. Res., 18, 365 (2004); https://doi.org/10.1002/ptr.1400.

36. T. de Brum, M. Zadra, M. Piana, A. Boligon, J. Fröhlich, R. de Freitas, S. Stefanello, A. Froeder, B. Belke, L. Nunes, R. da Silva Jesus, M. Machado, J. Teixeira da Rocha, F. Soares and M. Athayde, Molecules, 18, 8342 (2013); https://doi.org/10.3390/molecules 18078342 .

37. M. Kassim, M. Achoui, M.R. Mustafa, M.A. Mohd and K.M. Yusoff, Nutr. Res., 30, 650 (2010); https://doi.org/10.1016/j.nutres.2010.08.008.

38. A. Ghasemzadeh and H. Jaafar, Sci. World J., 1, 10 (2014).

39. S. Zhang, Y. Lin, H. Zhou, S. Wei, G. Lin and G. Ye, Molecules, 15, 5658 (2010); https://doi.org/10.3390/molecules 15085658.

40. S. Kaur and P. Mondal, J. Microbiol. Exp., 1, 23 (2014); https://doi.org/10.15406/jmen.2014.01.00005. 